\title{
Interstitial Lung Disease due to Quetiapine: Case Report and Literature Review
}

\author{
Ketiapine Bağlı İnterstisyel Akciğer Hastalığı: Olgu Sunumu ve Literatür İncelemesi
}

\author{
Müge TOPCUOĞLU \\ (1) 0000-0002-7098-8806 \\ Ali ERDOĞAN \\ (D) 0000-0003-0329-6778
}

Akdeniz University Medical Faculty Department of Psychiatry, Antalya, Turkey

\section{Corresponding Author \\ Sorumlu Yazar \\ Ali ERDOĞAN \\ erdoganali006@hotmail.com}

Received / Geliş Tarihi : 05.05.2020

Accepted / Kabul Tarihi : 21.07.2020

Available Online /

Çevrimiçi Yayın Tarihi : 25.08.2020

\begin{abstract}
Quetiapine is a commonly used antipsychotic drug which has many common side effects such as dizziness, sedation, and metabolic side effects. In addition to them, the drug has also some rare side effects. Among them, little is known about drug-induced interstitial lung disease (DIILD). In this case report, we aimed to discuss the side effects of quetiapine use on the lung. We present a case of interstitial lung disease, which is rare side effect, that occurred following quetiapine use in a 54-year-old male schizophrenia patient. In our case, DI-ILD was examined due to the lung findings that occurred after quetiapine treatment started and regressed after quetiapine cessation. Clinicians should be careful about rare lung side effects such as DI-ILD that may develop as a result of quetiapine use.

Keywords: Interstitial lung disease; quetiapine; schizophrenia.
\end{abstract}

ÖZ

Ketiapin yaygın kullanılan, baş dönmesi, sedasyon ve metabolik yan etkiler gibi birçok yaygın yan etkisi olan bir antipsikotik ilaçtır. Bunlara ek olarak, ilacın bazı nadir yan etkileri de mevcuttur. Bunlar arasında ilaca bağlı interstisyel akciğer hastalığı (drug-induced interstitial lung disease, DI-ILD) çok az bilinmektedir. Bu olgu sunumunda ketiapin kullanımının akciğer yan etkilerini tartışmayı amaçladık. Elli dört yaşında erkek bir şizofreni hastasında ketiapin kullanımını takiben ortaya çıkan, nadir görülen bir yan etki olan interstisyel akciğer hastalığı olgusu sunulmaktadır. Olgumuzda, ketiapin tedavisinin başlamasından sonra ortaya çıkan ve ketiapin kesildikten sonra gerileyen akciğer bulguları nedeniyle DI-ILD düşünülmüştür. Klinisyenler, ketiapin kullanımının bir sonucu olarak ortaya çıkabilecek DI-ILD gibi nadir akciğer yan etkileri konusunda dikkatli olmalıdır.

Anahtar kelimeler: Interstisyel akciğer hastalı̆̆ı; ketiapin; şizofreni.

\section{INTRODUCTION}

Quetiapine is an atypical antipsychotic that is used in the treatment of psychiatric disorders such as schizophrenia, bipolar disorder, and major depressive disorder (1). Quetiapine causes various side effects such as prolonged QT interval, metabolic disorder, hypothyroidism and hepatic dysfunction. However, side effects in the respiratory system are less common (2). As an example, drug-induced interstitial lung disease (DI-ILD) is a diagnostic problem due to its nonspecific clinical presentation. It is diagnosed by the use of drugs and the development of symptoms, the presence of infiltration sites in the lungs, the exclusion of other causes, and the regression of symptoms after discontinuation of the drug (3). In this article, we present a patient with DI-ILD due to quetiapine therapy and we aimed to contribute to the medical literature by our clinical experience and discussing the side effects of quetiapine use on the lung system. 


\section{CASE REPORT}

A 54-year-old male patient was admitted to our outpatient clinic due to psychotic exacerbation and was referred to our clinic. The patient had a history of schizophrenia for 34 years, and aggression, paranoid delusions. Auditory hallucinations had begun again for the past 15 days. In addition, the patient had high fever, cough, sputum and shortness of breath. Besides, it was learned that his complaints started one week before the admission.

In the psychiatric examination, the patient had decreased self-care, his orientation was normal, his speech was normal, and his psychomotor activity was increased. He had paranoid delusions, auditory and visual hallucinations. Respiratory system examination revealed diffuse inspiratory rales in the bilateral middle and lower regions of the lungs. Other system examination findings were within normal limits.

He had a history of 50-year-smoking addict and had quit smoking one year ago. There was no history of alcohol or substance use. The patient had no previous history of lung disease, allergy, and medical history. The patient's blood pressure was $110 / 70 \mathrm{~mm} \mathrm{Hg}$, body temperature was $37.8^{\circ} \mathrm{C}$ (axillary), pulse rate was 112 beats/min and respiratory rate was 26 breaths/min. Laboratory tests had mild high Creactive protein $(7.4 \mathrm{mg} / \mathrm{L}$, reference range: $0-5 \mathrm{mg} / \mathrm{L})$ and mild leukocytosis $\left(13 \times 10^{9} / \mathrm{L}\right.$, reference range: $4.5-11 \times 10^{9}$ $/ \mathrm{L})$. All other laboratory parameters were within normal ranges. Hepatitis viruses and Human Immunodeficiency Virus (HIV) markers were negative. Arterial blood gas analysis revealed $\mathrm{pH}$ was $7.46, \mathrm{PaO}_{2}$ was $92.6 \mathrm{~mm} \mathrm{Hg}$, $\mathrm{PCO}_{2}$ was $32.8 \mathrm{~mm} \mathrm{Hg}$, bicarbonate concentration was $22.9 \mathrm{mmol} / \mathrm{L}$ and oxygen saturation was $89 \%$.

The patient has been using clozapine $350 \mathrm{mg} /$ day for 10 years, aripiprazole $20 \mathrm{mg} /$ day for 1.5 years, amisulpride $800 \mathrm{mg} /$ day for 6 years and quetiapine $300 \mathrm{mg} /$ day for 5 months. Although the patient had a history of treatment with various antipsychotic drugs, the important point was that he started to use quetiapine about 5 months before his admission to our clinic.

The patient's echocardiogram was normal. Infiltrated areas were seen on chest X-ray (Figure 1). In thorax computed tomography and high resolution computed tomography (HRCT), centrilobular nodular appearances of peribroncovascular diffuse ground glass density involving both lower lobes were observed (Figure 2). Significant progressive changes in the lung were observed when the lung radiographies were compared with the previous ones. Pulmonary function test showed restrictive pattern and decreased diffusion capacity (FEV1/FVC: $80 \%$ and DLCO: $60 \%$ ).

His urine and blood culture results were sterile. First, the patient was diagnosed with interstitial pneumonia and oral moxifloxacin $400 \mathrm{mg} /$ day treatment was initiated. Bronchoalveolar lavage and bronchoscopy were performed for diagnostic purposes. Tracheal aspirate culture was examined. Bronchoscopy revealed normal vocal cords and trachea. In both bronchial systems, all segments and subsegments were open and purulent secretions were present. There was no endobronchial lesion. No pathogen was seen in bronchoalveolar lavage culture. $20 \%$ alveolar-macrophage, $10 \%$ lymphocyte and $70 \%$ neutrophils were observed in bronchoalveolar lavage, but no eosinophils were detected. Tracheal aspirate culture showed polymorphonuclear lymphocytes (PNL) and labile cocci. Viral and mycobacterial cultures prepared from aspirates were negative. The patient and his relatives refused thoracoscopic and trans-bronchial lung biopsy.

In clinical and laboratory findings, the patient did not respond adequately to oral medical therapy. Therefore, intravenous piperacillin/tazobactam combination (4,5 gr, once daily) was used instead of the current oral treatment. Although there was no histopathological evidence, we suspected the patient to be DI-ILD, because the patient did not respond to antibiotic therapy, and the existing HRCT findings overlapped DI-ILD. We did not detect any environmental exposure, infection, or rheumatologic process in the patient. He had been using other antipsychotics for a very long time and quetiapine was the last drug exposure. So we thought DI-ILD might be related to quetiapine and, quetiapine was discontinued. Adequate response was obtained in clinical and laboratory parameters within approximately 10 days. The patient's cough decreased and lung auscultation was normal. The pre-discharge control chest X-ray and HRCT showed regression in alveolar infiltration. Based on all these data, the possible agent causing the disease appears to be quetiapine.

\section{DISCUSSION}

In our case report, we presented an interstitial lung disease case due to the quetiapine administration. Based on clinical symptoms, laboratory, and radiological findings, we suspected that the patient had pneumonia. Therefore, in the first step, we applied empirical antibiotic therapy. Since there was no improvement in the patient's clinical symptoms, DI-ILD was diagnosed after reassessment of the case.

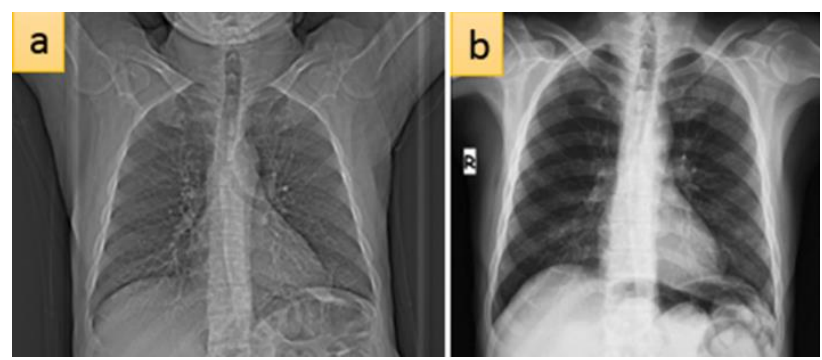

Figure 1. a) Chest X-ray of patient when using quetiapine. b) Infiltrations regress almost completely on chest X-ray one month after cessation of quetiapine treatment.

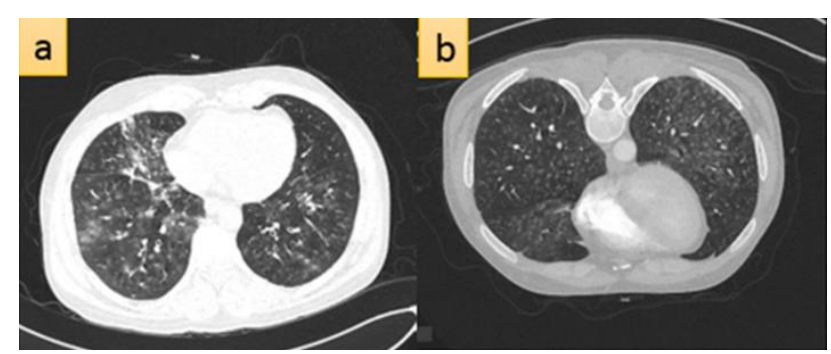

Figure 2. a) High resolution computed tomography (HRCT) of the patient with bilateral micronodular and diffuse ground glass opacities when using quetiapine. b) One month after cessation of quetiapine treatment, the infiltrations in HRCT almost completely regressed 
In case reports, it has been reported that DI-ILD develops with psychiatric drugs such as paroxetine, sertraline, clozapine and risperidone (4). Rarely, DI-ILD has been reported with some antipsychotics, such as clozapine (3). Quetiapine which is an atypical antipsychotic drug has many known side effects. However, DI-ILD which is one of the respiratory system side effects of quetiapine is rare (5). In a new study, in critically injured trauma patients, quetiapine exposure was associated with increased pulmonary complications (PC) risk. Patients administered quetiapine were more likely to develop PC and acquire PC earlier than those without quetiapine. Quetiapine has reported a positive risk factor for PC (6). Diagnosis of DIILD usually depends on the association between a history of medication and the onset and progression of respiratory complaints. The most important factor in making the accurate diagnosis is the exclusion of other causes of lung damage such as infections. Laboratory findings and nonspecific clinical symptoms of DI-ILD such as fever, cough, dyspnea and hypoxemia make the diagnosis difficult. Studies have suggested that cytotoxic lung injury and immune-mediated damage are mechanisms of DI-ILD (7). Some drugs may disrupt the blood-alveolar barrier by making a direct toxic effect on endothelial cells in the lungs. Thus, proteins that pass through the alveoli form hyaline membranes and exudate type fluid causes hypoxia. If exposure to the drug continues during this period, nonspecific interstitial pneumonia or lymphocytic interstitial pneumonia patterns may occur. Immunitymediated damage is usually T-cell mediated (8). In addition to these mechanisms, Wijnen et al. (9) found that various cytochrome-P450 (CYP) genotypes posed a risk of susceptibility to the development of DI-ILD in individuals. CYP2D6, a high-affinity-low-capacity enzyme, prefers to metabolize drugs at lower concentrations. CYP3A4 activity decreases with hepatic dysfunction and CYP2D6 plays an important role in metabolizing quetiapine, especially at a lower concentration. Since the lungs contain CYP2D6 enzyme systems, quetiapine is thought to contribute to CYP-mediated damage.

In our case, we do not know the histopathological diagnosis. The patient had no environmental exposure, occupational disease, or rheumatologic process that explain the symptoms and signs. Eosinophilic lung diseases such as eosinophilic pneumonia, Churg Strauss Syndrome and allergic bronchopulmonary aspergillosis were excluded due to a lack of normal peripheric eosinophil counts and radiological pattern. Our patient did not respond to various antibiotic treatments. Quetiapine was the last drug exposure to the patient. In addition, after discontinuation of quetiapine, chest radiography findings and the patient's symptoms improved rapidly. With all these findings, we diagnosed the interstitial lung disease that developed as a result of the patient's quetiapine use. This case highlights that quetiapine may be one of the possible causes of DI-ILD. We recommend that clinicians should be careful about the rare side effects of quetiapine, such as interstitial lung disease, other than the common side effects.

\section{Informed Consent}

Written informed consent was obtained from the patient for publication.

\section{REFERENCES}

1. Devlin JW, Roberts RJ, Fong JJ, Skrobik Y, Riker RR, Hill NS, et al. Efficacy and safety of quetiapine in critically ill patients with delirium: a prospective, multicenter, randomized, double-blind, placebocontrolled pilot study. Crit Care Med. 2010;38(2):41927.

2. Eyer F, Pfab R, Felgenhauer N, Strubel T, Saugel B, Zilker T. Clinical and analytical features of severe suicidal quetiapine overdoses--a retrospective cohort study. Clin Toxicol (Phila). 2011;49(9):846-53.

3. Can KC, Karnak D, Özgüven HD. A very rare adverse effect of clozapine, clozapine-induced interstitial lung disease: Case report and literature review. Noro Psikiyatr Ars. 2019;56(4):313-5.

4. Chen XF, Peng SC, Li J, Wei LQ, Zhang YH. Interstitial lung disease caused by psychiatric drug therapy. Int J Clin Exp Pathol. 2016;9(2):1706-12.

5. Kim SJ, Han SD, Lee JY, Chon GR. A case of druginduced interstitial pneumonia potentially related to quetiapine (seroquel) therapy for behavioral and psychological symptoms. Respir Care. 2014;59(10):e145-8.

6. Wessels LE, Wallace JD, Calvo RY, Levko T, Bowie JM, Butler WJ, et al. Quetiapine therapy in critically injured trauma patients is associated with an increased risk of pulmonary complications. Am J Surg. 2020;219(5):804-9.

7. Matsuno O. Drug-induced interstitial lung disease: mechanisms and best diagnostic approaches. Respir Res. 2012;13(1):39.

8. Popper HH. Interstitial lung diseases-can pathologists arrive at an etiology-based diagnosis? A critical update. Virchows Arch. 2013;462(1):1-26.

9. Wijnen PA, Bekers O, Drent M. Relationship between drug-induced interstitial lung diseases and cytochrome P450 polymorphisms. Curr Opin Pulm Med. 2010;16(5):496-502. 